\title{
Effect of 7-Dehydrocholesterol on Ram Semen Spermatological Parameters on Short Term Preservation
}

\author{
Muhammed Enes İNANÇ* ${ }^{*}$, Şükrü GÜNGÖR ${ }^{1}$, Ayhan ATA ${ }^{1}$ \\ ${ }^{1}$ Mehmet Akif Ersoy University, Faculty of Veterinary Medicine, Department of Reproduction and Artificial Insemination, TR- \\ 15030 Burdur - TURKEY
}

\begin{abstract}
The aim of this study was investigated to effect of 7-dehydrocholesterol loaded cyclodextrin (7-DCLC) on ram semen spermatological parameters on short term preservation at $+4{ }^{0} \mathrm{C}$. Collected semen with electroejaculator at non-breeding season. Each animal native ejaculates were mixed and divided into 4 equal groups, diluated with tris/egg yolk extender with included different rates of 7-DCLC (1.5 mg, $3.0 \mathrm{mg}$ and $\left.5 \mathrm{mg} / 120 \times 10^{6}\right)$ and control (C). After extended semen samples were preservation at $+4{ }^{0} \mathrm{C}$ and evaluated motility, membrane integrity and abnormal spermatozoa rate until 96. hour. There were no significant differences between the groups on abnormal spermatozoa rate $(\mathrm{P}>0.05)$; there were a significant differences between the groups on motility at all storage period $(\mathrm{P}<0.05)$. The highest motility were observed in 7-DCLC $1.5 \mathrm{mg}$ at 72 . and 96 . hour $(\mathrm{P}<0.05)$. The highest dose $\left(5 \mathrm{mg} / 120 \times 10^{6}\right) 7$-DCLC were decreased the motility and membrane integrity compared to other groups. Besides, 7-DCLC $3.0 \mathrm{mg}$ group membrane integrity was lower than control at 72 . hour $(\mathrm{P}<0.05)$. In conclusion, tris/egg yolk extender which is contain 7-DCLC $1.5 \mathrm{mg}$ were protected to ram semen motility and membrane integrity up to 96 . hour at $+4^{\circ} \mathrm{C}$ preservation.
\end{abstract}

Keywords: 7-dehydrocholesterol, cyclodextrins, motility, membrane integrity, short term storage.

\section{Kısa Süreli Saklanan Koç Spermasında 7-Dehidrokolesterolün Spermatolojik Parametrelere Etkisi}

ÖZ

Bu çalışmanın amacı, 7-dehidrokolesterol yüklenmiş siklodekstrinin (7-DCLC) +4 $\mathrm{C}^{0}$ 'de kısa süreli saklanan koç spermasının spermatolojik parametrelerine etkisinin araştırılmasıdır. Her bir hayvandan spermalar elektroejakülatör yardımı ile sezon dışında alınarak dört eşit gruba ayrıldı, farklı oranlarda 7-DCLC (1,5 mg, 3,0 $\mathrm{mg}$ and $5 \mathrm{mg} / 120 \times 10^{\circ}$ ) içeren ve içermeyen kontrol (C) tris/yumurta sarısı sulandırıcı ile sulandırıldı. Sulandırılan spermalar, $+4 \mathrm{C}^{0}$ 'de saklanarak 96 saat süresince motilite, membran bütünlüğü ve anormal spermatozoa yönünden incelendi. Saklama süresi boyunca anormal spermatozoa yönünden gruplar arasında bir farklil1k bulunmazken (P>0,05); motilite açısından gruplar arasında farklılıklar tespit edildi $(\mathrm{P}<0,05)$. 72. ve 96. zaman dilimlerinde en yüksek motilite 7-DCLC $1,5 \mathrm{mg} / 120 \times 10^{6}$ grubunda tespit edildi $(\mathrm{P}<0,05)$. En yüksek dozlu $(5 \mathrm{mg})$ 7-DCLC grubu diğer gruplarla karşılaştırıldığında spermatozoa motilitesini ve membran bütünlüğünü düşürdügü tespit edildi. Ayrıca, 72. saatte 7-DCLC 3,0 mg grubunun membran bütünlüğü kontrol grubuna göre daha az olduğu tespit edildi $(\mathrm{P}<0,05)$. Sonuç olarak, 7-DCLC 1,5 $\mathrm{mg}$ içeren tris/yumurta sarıs1 sulandırıcıs1 koç spermasında motiliteyi ve membran bütünlügünü $+4 \mathrm{C}^{0}$ 'de 96 saat süresince koruduğu belirlendi.

Anahtar Kelimeler: 7-dehidrokolesterol, siklodekstrin, motilite, membran bütünlüğü, kısa süreli saklama

To cite this article: Inanç M.E. Güngör S. Ata A. Effect of 7-Dehydrocholesterol on Ram Semen Spermatological Parameters on Short Term Preservation. Kocatepe Vet J. (2019) 12(1):15-19 


\section{INTRODUCTION}

The artificial insemination technology can simplify sheep industry (O'Hara et al. 2010) and one of the important factors for spread to superior genotypes (Falchi et al. 2018). In this technology, semen cryopreservation is the most used preservation type in farm animals (Bucak et al. 2008). Some authors reported that cervical artificial insemination with frozen-thawed semen generally results in lower pregnancy than fresh or short therm preservation (Maxwell et al. 1999, Paulenz et al. 2002). The low fertilization from cervical artificial insemination with frozen-thawed semen is based on the irreversible damage at cryopreservation process (Salamon and Maxwell 1995, Bailey et al. 2000). The low proportion of ram semen biologically protect to their cell membrane and can capable to pass cervical barrier and reach to fertilization site at the cervical artificial insemination (Salamon and Maxwell 2000, O'Hara et al. 2010). In cryopreservation high proportion of ram spermatozoa cells have under goes damage during freezing-thawing process. Especially spermatozoon viability, membrane integrity and motility has been decreased (Salamon and Maxwell 1995, De Lamirande et al. 1997). These problems caused by freezing resulted in the keeping of the ram's sperm at $+4{ }^{0} \mathrm{C}$. The loss of motility, membrane integrity and fertilization is observed more gradually in the storage of semen at $+4{ }^{0} \mathrm{C}$ (Maxwell and Watson, 1996, Avdatek et al. 2018).

Ram semen has a lower cholesterol/phospholipid and higher polyunsaturated/fatty acids rate than other animal species (Moce et al. 2010). Cholesterol has a multi type effect on the plasma membrane; acts as a membrane antioxidant, decreases membrane permeability, ensures a suitable chemical and/or physical microenvironment for proteins in the membrane and reduces phase changes, regulates morphological characteristics (Aksoy et al. 2010, Moce et al. 2010). On the other hand, cyclodextrins are commonly defined as cyclic oligosaccharides produced by the breakdown of starch (Crini 2014). There are also some reports supplemented cholesterol loaded cyclodextrin (CLC) into different animal species for semen preservation and increased phospholipid-cholesterol ratio (Purdy and Graham 2004, Murphy et al. 2014). This increase has been protected to morphological integrity (Mansour 2009), DNA damage (Katanbegzadeh et al. 2014), motility, viability and membrane integrity (Purdy et al. 2004).

7-dehydrocholesterol is intermediate product of cholesterol in biochemical shema and it's one of the cholesterol conjugate. 7 dehydrocholesterol is formed prior to cholesterol is produced. In previous studies have demonstrated the protective effects of 7-DCLC supplementation on in vitro spermatological parameters of frozen ram semen (Inanc et al. 2018a) and chilled bull semen (Inanc et al. 2017). But there are no information about ram semen short term preservation studies with 7-DCLC in tris extender. Thus, the aim of this study was investigated to effect of 7-DCLC on ram semen spermatological parameters on short term preservation at $+4 \mathrm{C}^{0}$.

\section{MATERIAL and METHOD}

\section{Cyclodextrin preparation}

Methyl-beta-cyclodextrin (MBC, C4555)- 7dehydrocholesterol (CAS number: SC 214398) complex prepared by Purdy and Graham (2004) method. Briefly, $1 \mathrm{~g}$ of MBC was solved in $2 \mathrm{ml}$ of methanol in test tube. $200 \mathrm{mg}$ 7-dehydrocholesterol was solved in $1 \mathrm{ml}$ chloroform in another test tube. After, $450 \mathrm{ml}$ 7-dehydrocholesterol was mixed with $\mathrm{MBC}$; solvents were evaporated with nitrogen vapor and finally 7-DCLC powders were obtained. 7-DCLC working solutions were prepared with $50 \mathrm{mg}$ 7DCLC; these were dissolved in $1 \mathrm{ml}$ of a stock tris solution in different test tube at $37{ }^{\circ} \mathrm{C}$ and the solution was mixed with vortex.

\section{Animal and Study Design}

In this study three mature Pirlak-Merino crossbred rams were used. The animals were submitted to special farm with uniform breeding conditions at the Çallica in Burdur, Turkey. 18 ejaculates were collected with electroejaculator (Minitube, e320). Every ejaculates were examined macroscobic and microscobic evaluation and good quality ejaculates (concentration: $\geq 2 \times 10^{9} / \mathrm{ml}$, volume $\geq 0.5 \mathrm{ml}$, motility: $\geq 80 \%$ ) were mixed. Mixed ejaculates were diveded equal four groups and control group without the additive into a tris-based extender (Tris, T1503; 3.63 gr; Citric acid, C0759; 1.82 gr; Glucose, G7528; $0.5 \mathrm{gr} / 100 \mathrm{ml}$ distilled water, $15 \%$ (v/v) egg yolk); other three groups which is contain 7-DCLC $(1.5 \mathrm{mg}$, $3.0 \mathrm{mg}, 5.0 \mathrm{mg} / 120 \times 10^{6}$ ) were firstly extended with 7 DCLC solutions and incubated for $15 \mathrm{~min}$ at $25^{\circ} \mathrm{C}$, then the groups were extended with a tris-based extender to a final concentration of $500 \times 10^{6}$ spermatozoa $/ \mathrm{mL}$. Extended semen groups were loaded to straws and they were considered as 0 . hours and stored at $+4{ }^{\circ} \mathrm{C}$ until 96 . hours. This study was approved by Mehmet Akif Ersoy University Animal Experiments Local Ethics Committee (06.12.2017/260).

\section{Spermatological Evaluation}

Subjective motility was analyzed using a phasecontrast microscope $\left(400 \times\right.$ magnification), at $37^{\circ} \mathrm{C}$. Sperm motility scores were performed in at least five different parts for each sample. The mean of the five successive evaluations was kept as the motility score. Evaluation of membrane integrity, Hypo-Osmotic Swelling (HOS) test was used and based on curled and swollen tails. This was determined by incubating 
$10 \mu \mathrm{L}$ of semen with $100 \mu \mathrm{L}$ of $100 \mathrm{mOsm}$ hypoosmotic fructose (D-Fructose F0127) solution at $37^{\circ} \mathrm{C}$ for $60 \mathrm{~min}$. Totally 200 spermatozoa were checked under $400 \times$ magnification and spermatozoa with coiled or swollen tails were recorded (Revell and Mrode 1994). Abnormal spermatozoon rate was determined by liquid fixation method. Spermatozoon were fixed with Hancock solution (Hancock 1952) and abnormalities detected under 1000x magnification with phase-contrast microscopy by evaluating at least 200 sperm cells (Schafer and Holzman 2000).

\section{Statistical Analysis}

The study was replicated six times. The results were expressed as Mean (X) \pm Standard Error (SEM). Means was analyzed using a one-way analysis of variance (ANOVA), followed by Tukey's post hoc test to determine the significant differences in all parameters among all groups using the SPSS/PC computer program (version 22.0). Differences with values of $\mathrm{P}<0.05$ were considered statistically significant.

\section{RESULTS}

There were no significant differences between the control and 7-DCLC $1.5 \mathrm{mg}$; 7-DCLC $3.0 \mathrm{mg}$ and 5.0 $\mathrm{mg}$ on motility at 0 . hour $(\mathrm{P}<0.05)$. The highest motility were observed in 7-DCLC $1.5 \mathrm{mg}$ at 48. Hour (Table 1). There were a significant differences between the groups on motility at 72 . and 96 . hours $(\mathrm{P}<0.05)$; the highest motility were $53.26 \pm 1.23 \%$; $48.03 \pm 1.88 \%$ in 7 -DCLC $1.5 \mathrm{mg}$ respectively. The highest dose $\left(5 \mathrm{mg} / 120 \times 10^{\circ}\right) 7$-DCLC were decreased the motility and membrane integrity compared to other groups. Besides, 7-DCLC $3.0 \mathrm{mg}$ group membrane integrity 33.65 $\pm 5.88 \%$ was lower than control at 72 . hour $(\mathrm{P}<0.05)$ (Table 2). Also, there were no significant differences between the groups on abnormal spermatozoa rate $(\mathrm{P}>0.05)$ at the storage period (Table 3).

Table 1. Mean ( \pm SEM) ram semen motility $(\%)$ of short term preservation with 7 -DCLC

\begin{tabular}{cccccc}
\hline Groups & 0. hour & 24. hour & 48. hour & 72. hour & 96. hour \\
\hline Control & $84.16 \pm 0.83^{\mathrm{a}}$ & $79.16 \pm 2.38^{\mathrm{a}}$ & $52.03 \pm 1.47^{\mathrm{a}}$ & $42.10 \pm 1.85^{\mathrm{b}}$ & $35.50 \pm 2.80^{\mathrm{b}}$ \\
7 DCLC 1.5 & $81.66 \pm 1.66^{\mathrm{a}}$ & $70.26 \pm 3.51^{\mathrm{a}}$ & $54.43 \pm 1.58^{\mathrm{a}}$ & $53.26 \pm 1.23^{\mathrm{a}}$ & $48.03 \pm 1.88^{\mathrm{a}}$ \\
7 DCLC 3.0 & $75.83 \pm 2.00^{\mathrm{b}}$ & $76.08 \pm 1.75^{\mathrm{a}}$ & $16.55 \pm 2.20^{\mathrm{b}}$ & $7.26 \pm 0.72^{\mathrm{c}}$ & - \\
7 DCLC 5.0 & $71.66 \pm 1.05^{\mathrm{b}}$ & $43.93 \pm 3.28^{\mathrm{b}}$ & $5.31 \pm 1.89^{\mathrm{c}}$ & $2.16 \pm 1.01^{\mathrm{c}}$ & - \\
\hline P & $*$ & $*$ & $*$ & $*$ & $*$
\end{tabular}

a-c: Different superscripts within the same column demonstrate significant differences $(\mathrm{P}<0.05)$.

a-c:Aynı sütunda farklı harf taşıyan gruplar istatistiksel olarak farklıdır $(\mathrm{P}<0,05)$.

Table 2. Mean ( \pm SEM) ram semen membrane integrity (HOS test, $\%$ ) of short term preservation with 7-DCLC

\begin{tabular}{cccccc}
\hline Groups & $\mathbf{0 . h o u r}$ & $\mathbf{2 4 . \text { hour }}$ & $\mathbf{4 8 .}$ hour & 72. hour & 96. hour \\
\hline Control & $66.36 \pm 3.44^{\mathrm{a}}$ & $59.98 \pm 1.87^{\mathrm{b}}$ & $54.09 \pm 6.31^{\mathrm{a}}$ & $50.78 \pm 2.63^{\mathrm{a}}$ & $38.58 \pm 4.69^{\mathrm{a}}$ \\
7 DCLC 1.5 & $60.94 \pm 2.55^{\mathrm{a}}$ & $52.08 \pm 3.06^{\mathrm{b}}$ & $47.76 \pm 3.63^{\mathrm{a}}$ & $43.54 \pm 4.25^{\mathrm{ab}}$ & $38.99 \pm 5.17^{\mathrm{a}}$ \\
7 DCLC 3.0 & $62.50 \pm 5.08^{\mathrm{a}}$ & $51.72 \pm 4.78^{\mathrm{b}}$ & $44.67 \pm 4.26^{\mathrm{a}}$ & $33.65 \pm 5.88^{\mathrm{bc}}$ & $25.12 \pm 5.59^{\mathrm{ab}}$ \\
7 DCLC 5.0 & $42.15 \pm 9.41^{\mathrm{b}}$ & $39.24 \pm 2.14^{\mathrm{a}}$ & $26.12 \pm 4.15^{\mathrm{b}}$ & $23.20 \pm 2.40^{\mathrm{b}}$ & $15.57 \pm 3.54^{\mathrm{b}}$ \\
\hline P & $*$ & $*$ & $*$ & $*$ & $*$ \\
\hline
\end{tabular}

a-c: Different superscripts within the same column demonstrate significant differences $(\mathrm{P}<0.05)$.

a-c: Aynı sütunda farklı harf taşıyan gruplar istatistiksel olarak farklıdır $(\mathrm{P}<0,05)$.

Table 3. Mean ( \pm SEM) ram semen total abnormal spermatozoa rate $(\%)$ of short term preservation with 7-DCLC

\begin{tabular}{lcc}
\hline Groups & 0. hour & $\mathbf{9 6 . ~ h o u r ~}$ \\
\hline Control & $12.81 \pm 0.90$ & $17.58 \pm 1.28$ \\
7 DCLC 1.5 & $10.60 \pm 2.01$ & $16.17 \pm 1.34$ \\
7 DCLC 3.0 & $8.87 \pm 1.31$ & $16.88 \pm 1.77$ \\
7 DCLC 5.0 & $8.07 \pm 1.09$ & $19.67 \pm 1.38$ \\
\hline P & - & -
\end{tabular}

$\mathbf{P}$

-: No significant difference ( $\mathrm{P}>0.05)$.

-: Gruplar arasinda istatistiki bir fark bulunmamaktadır $(\mathrm{P}>0,05)$.

\section{DISCUSSION}

This study performed to evaluation the effect of short term storage with tris based extender supplementation with 7-DCLC. 7-DCLC $1.5 \mathrm{mg}$ were improved to motility at started by 72 . hour
$(53.26 \pm 1.23 \%) \quad(\mathrm{P}<0.05)$. As the same results were observed in 96. hour $(\mathrm{P}<0.05)$. Amorim et al. (2009) and Moraes et al. (2010) cryopreservation of bull semen with cholestryl conjugates and they were observed improved to motility compared to control group. Benhenia et al. (2018) was frozen ram semen 
with tris-egg yolk extender containing with CLC (2 $\left.\mathrm{mg} / 120 \mathrm{x} 10^{6}\right)+$ Vit E combination. They were had a significant positive effect on progressive motility, total motility and membrane integrity. On the other hand, Oliveria et al. (2014) didn't find any significant differences between the CLC and control groups spermatozoa velocity after thawed the donkey semen. But, like present study, Inanc et al. (2017) preserved bull semen at $+4{ }^{\circ} \mathrm{C}$ up to 72 . hour with 7-DCLC and CLC. They were found 7-DCLC decreased the cell damage at the low temperature by the had improved to motility compared to control. Also, CLC 1.5 $\mathrm{mg} / 120 \times 10^{6}$ was found to good option at $+4{ }^{0} \mathrm{C}$ liquid storage in this study. These results showed that low level of 7 - DCLC $\left(1.5 \mathrm{mg} / 120 \times 10^{\circ}\right)$ had increased membrane lipid protein structure. This could be caused increased osmotic changes into the cell membranes. Besides, the high level 7-DCLC group $\left(5 \mathrm{mg} / 120 \times 10^{6}\right)$ decreased the motility at the all of the preservation time.

Membrane integrity in spermatozoa can be evaluated simply by the HOS test. (Revell and Mrode 1994). In present study, the highest dose $\left(5 \mathrm{mg} / 120 \times 10^{6}\right) 7$ DCLC were decreased the membrane integrity compared to other groups. Partyka et al. (2018) were supported present study and highest level CLC (4 $\mathrm{mg} / 120 \mathrm{x} 10^{6}$ ) had the lowest membrane integrity and motility in fresh and short term preservation chicken spermatozoa at $+5{ }^{0} \mathrm{C}$. Besides, 7-DCLC $3.0 \mathrm{mg}$ membrane integrity 33.65 $5.88 \%$ was lower than control at 72 . hour $(\mathrm{P}<0.05)$. Inanc et al. (2018a) frozen-thawed ram semen and they found improvement to membrane integrity with 7-DCLC compared to control groups. Membrane integrity was increased with CLC supplementation in bull semen after freeze-thawing procedure (Purdy and Graham 2004). On the other hand, cholesterol modification in the cell membrane protects antioxidative enzymes and prevents spreading to reactive oxidative species (Lopez-Revuelta et al. 2007). Medeiros et al. (2002) observed that phospholipid / cholesterol rate is a good achive for evaluate the stability membrane and fluidity at lower temperature. All this information suggest that cholesterol, cholesterol conjugate and forms support to membrane integrity and support to our results.

In present study, there were no significant differences between the groups on abnormal spermatozoa rate $(\mathrm{P}>0.05)$ at the storage period. Oettle (1993) stated that low level morphological integrity was shown to be an important marker of infertility. CLC did not increase the total morphological integrity (Khan et al. 2017, Inanc et al. 2018b). This results were similar with current study findings. But there were same significant differences between the cholesterol conjugate and control groups after freze-thawed process (Moce et al. 2010). This differences could be explain by different animal genotype and breed, different freezing-thawing procedure. Some researcher found high apoptotic level in the whole groups after cryopreservation procedure (Inoue et al. 1999, Inanc et al. 2018a). This could be occurred as a result of our freezing-thawing procedure. This apoptosis might be results higher abnormal spermatozoa rate compared to fresh or short term (liquid) storage conditions. By this way, short term storage should be used for higher fertility compared to freezing-thawing procedure.

In conclusion, tris/egg yolk extender which is supplementation 7-DCLC $1.5 \mathrm{mg} / 120 \times 10^{6}$ was protected to ram semen motility and membrane integrity up to 96 . hour at $+4^{\circ} \mathrm{C}$ preservation. 7DCLC $1.5 \mathrm{mg} / 120 \times 10^{6}$ can be used in short-term artificial insemination applications in sheep breeding industry.

\section{ACKNOWLEDGEMENT}

\section{Mehmet Akif Ersoy Üniversitesi Hayvan Deneyleri Yerel Etik. Kurulu (06.12.2017/260)}

\section{REFERENCES}

Aksoy M, Akman O, Lehimcioglu NC, Erdem H. Cholesterol-loaded cyclodextrin enhances osmotic tolerance and inhibits the acrosome reaction in rabbit spermatozoa. Anim Reprod Sci. 2010; 120: 166-172.

Amorim EAM, Graham JK, Spizziri B, Meyers M, Torres CA. Effect of cholesterol or cholesteryl conjugates on the cryosurvival of bull sperm. Cryobiology. 2009; 58: 210214.

Avdatek F, Yeni D, Gundogan M. Merinos koçlarda spermaya katılan antioksidanların kisa süreli saklama sırasında spermatolojik parametreler ve DNA hasar1 üzerine etkileri. Kocatepe Vet J. 2018; 11: 126-133.

Bailey JL, Bilodeau JF, Cormier N. Semen cryopreservation in domestic animals: a damaging and capacitating phenomenon. J Androl. 2000; 21: 1-7.

Benhenia K, Rahab H, Smadi MA, Benmakhlouf H, Lamara A, Idres T, Iguer-Ouanda M. Benifical and harmful effects of cyclodextrin- vitamin $\mathrm{E}$ complex on cryopreserved ram sperm. Anim. Reprod. Sci. 2018; 195; 266-273.

Bucak MN, Atessahin A, Yuce A. Effect of anti-oxidants and oxidativestress parameters on ram semen after the freezing-thawing process. Small Rum Res. 2008; 75: 128134.

Crini G. A history of cyclodextrins. Chemical reviews. 2014; 114: 10940-10975.

De Lamirande E, Leclerc P, Gagnon C. Capacitation as a regulatory event that primes spermatozoa for the acrosome reaction and fertilization. Mol Hum Reprod. 1997; 3: 175-194.

Falchi L, Gallerib G, Zeddaa MT, Paua S, Boglioloa L, Ariua F, Leddaa S. Liquid storage of ram semen for 96 h: Effects on kinematic parameters, membranes and DNA integrity and ROS production. Livestock Science. 2018; 207: 1-6. 
Hancock JL. The morphology of bull spermatozoa. J Exp Biol. 1952; 29: 445-453.

Inanc ME, Tekin K, Olgac KT, Ozen D, Stelletta C, Uysal O, Daskin A. Effects of 7-dehydrocholesterol and cholesterol-loaded cyclodextrins on bull sperm motility during short term storage. Kafkas Univ Vet Fak Derg. 2017; 23: 661-664.

Inanc ME, Uysal O, Ata A. Cryopreservation and evalution of Akkaraman ram semen with 7-dehydrocholesterol. Ankara Univ Vet Fak Derg. 2018a; 65: 179-185.

Inanc ME, Tekin K, Olgac KT, Yilmaz B, Cil B, Tasdemir U, Tuncer PB, Buyukleblebici S, Durmaz E, Uysal O. Effect of cholesterol loaded cyclodextrin on semen cryopreservation of Aksaray Malakli shepherd dogs of different ages. Animal Reprod Sci. 2018b; 193, 191-200.

Inoue K, Kubota S, Seyama Y. Cholestanol induces apoptosis of cerebellar neuronal cells, biochemical and biophysical. Biochemical and Biophys Res Commun. 1999; 256: 198203.

Katanbegzadeh H, Farid B, Mohammadreza T. Cryoprotectant-free freezing of the goat epididymal sperm. Cryoletters. 2014; 35: 293-298.

Khan J, Tahir MZ, Khalid A, Sattar A, Ahmad N. Effect of cholesterol-loaded cyclodextrins on cryosurvival of dog spermatozoa. Reprod Domest Anim. 2017; 52: 265-268.

Lopez-Revuelta A, Sanchez-Gallego JI, Garcia-Montero AC, Hernández-Hernández A, Sánchez-Yague J, Llanillo M. Membrane cholesterol in the regulation of aminophospholipid asymetry and phagocytosis in oxidized erythrocytes. Free Radical Bio Med. 2007; 42: 1106-1118.

Mansour M. Modification of hypo-osmotic swelling test to evaluate the integrity of stallion sperm plasma membrane. Global Veterinaria. 2009; 3: 302-307.

Maxwell WMC, Watson PF. Recent progress in the preservation of ram semen. Anim Reprod Sci. 1996; 42: $55-65$.

Maxwell WM, Evans G, Mortimer ST, Gillan L, Gellatly ES, McPhie CA. Normal fertility in ewes after cervical insemination with frozen-thawedspermatozoa supplemented with seminal plasma. Reprod Fertil Dev. 1999; 11: 123-126.

Medeiros CMO, Forell F, Oliveria ATD, Rodrigues JL. Current status of sperm cryopreservation: why isn't it better? Theriogenology. 2002; 57: 327-344.

Moce E, Blanch E, Tomás C, Graham JK. Use of cholesterol in sperm cryopreservation: Present moment and perspectives to future. Reprod Domest Anim. 2010; 45: 57-66.

Moraes EA, Graham JK, Torres CA, Meyers M, Torres CA. Delivering cholesterol or cholestanol to bull sperm membranes improves. cryosurvival. Anim Reprod Sci, 2010; 118: 148-54.

Murphy C, English AM, Holden SA, Fair S. Cholesterolloaded-cyclodextrins improve the post-thaw quality of stallion sperm. Anim Reprod Sci. 2014; 145: 123-129.

O'Hara L, Hanrahan JP, Richardson L, Donovan A, Fair S, Evans ACO, Lonergan P. Effect of storage duration, storage temperature, and diluent on the viability and fertility of fresh ram sperm. Theriogenology. 2010; 73: 541-549.

Oettle EE. Sperm morphology and fertility in the dog. J Reprod Fertil. 1993; Supplement 47: 257-260.
Oliveria RR, Rates DM, Pugliesi G, Ker PG, Arruda RP, Moraes EA, Carvalho GR. Use of cholesterol-loaded cyclodextrin in donkey semen cryopreservation improves sperm viability but results in low fertility in mares. Reprod Domest Anim. 2014; 49: 845-850.

Partyka A, Strojecki M, Niżański W. Cyclodextrins or cholesterol-loaded-cyclodextrins? A better choice for improved cryosurvival of chicken spermatozoa. Anim Reprod Sci. 2018; 193: 235-244.

Paulenz H, Soderquist L, Perez-Pe R, Berg KA. Effect of different extenders and storage temperatures on sperm viability of liquid ram semen. Theriogenology. 2002; 57 : 823-36.

Purdy PH, Graham JK. Effect of cholesterol-loaded cyclodextrin on the cryosurvival of bull sperm. Cryobiology. 2004; 48: 36-45.

Revell SG, Mrode RA. An osmotic resistance test for bovine semen. Anim Reprod Sci. 1994; 36: 77-86.

Salamon S, Maxwell WMC. Frozen storage of ram semen. 2. causes of low fertility after cervical insemination and methods of improvement. Anim Reprod Sci. 1995; 38:136.

Salamon S, Maxwell WM. Storage of ram semen. Anim Reprod Sci. 2000; 62: 77-111.

Schafer S, Holzmann A. The use of transmigration and spermac stain to evaluate epididymal cat spermatozoa. Anim Reprod Sci. 2000; 59: 201-11. 